Studia Ceranea 3, 2013, p. 197-212

Bogusław Andrzej Baczyński (Tarnów)

Małgorzata Baczyńska (Thessaloniki)

To Anna - A Wife and Mother

\title{
The Testament Donation of Knyaz Fedor Sanguszko for the Monastery of St. Paul of Xeropotamou on the Holy Mount Athos (9 ${ }^{\mathrm{TH}}$ November 1547)
}

The aim of this article is to present several comments on the subject of the original Volhynian testament donation for the monastery of St. Paul of Xeropotamou on the Holy Mount Athos. The benefactor was knyaz Fedor Andreevič Sanguszko (Sanguškovič), marshall of the Volhynia, starosta of Volodymyr and Vinnytsia, who throughout his hard-working life gathered a great fortune in Volhynia ${ }^{1}$, gaining royal recognition and high social status ${ }^{2}$, and at the end of his life distributed his wealth, taking care to ensure financial security for his wife and children, as well as to provide for his body and soul after his death.

The Sanguszkos (initially also Sanguškoviče) were one of the twenty aristocratic Lithuanian families, which controlled thirty percent of the Grand Duchy's lands. The remaining area was owned by nineteen thousand minor boyars. The military review drawn up in 1528 gives a clear picture of the aristocratic dominance during the early years of knyaz Fedor's activity. The Sanguszko family was placed only at the $12^{\text {th }}$ position, fielding 170 knights, from the 2720 farms they owned ${ }^{3}$. The first known document in which the financial matters of the Sanguszkos are present (in the person of knyaz Fedor's ancestor, father of Alexander, the progenitor of the Kamien Košyrski and Nesuchoeže branches of the family and Michał, the progenitor of the Kovel line) is the act of delimitation of his property Frol from

1 A. JabŁonowski, Ziemia wołyńska w połowie XVI wieku (Monografia), [in:] Rewizya zamków ziemi wołyńskiej w połowie XVI wieku, ed. IDEM, Warszawa 1877, p. XCIV-XCV [= Źródła dziejowe, 6].

2 Ibidem, p. XXV-XXVI: According to the review of 1545, we have found the names of the chief Volodymyr notables of this period. From knyaz families: Sanguszkos, of Kovel and Košyr, from among the knyazes, and of whom Fedor Andreevič was the local starosta and the marshall of all of Volhynia; the Wiszniowiecki family - Alexander, the lease holder (dzierżawca) of Žečyca; the Czartoryski family; and the minor families, such as Porycki, Kurcewicz, Koziaka and Jerhowicki (or Rohowicki) of Horuv and Ružyn (transl. M. Zytka).

3 Перапіс войска Вялікага княства Літоўскага 1528 г., Мінск 2003; J. Оснмаќsкі, Historia Litwy, Wrocław 1979, p. 106; T. KeMPA, Dzieje rodu Ostrogskich, Toruń 2003, p. 44. 
Ostroh ${ }^{4}$, issued on the eve of the feast of Luke the Evangelist, on $17^{\text {th }}$ of October 1423. The document is known from a transumpt of Władysław III from 1444, where it is mentioned. Further preserved documents from $15^{\text {th }}$ and $16^{\text {th }}$ centuries allow the recreation of the economic situation of the family and its ties to the royal court ${ }^{5}$.

On the $25^{\text {th }}$ of September 1539, in Cracow, king Sigismund I confirmed for knyaz Fedor Andreevic Sanguszko, the marshall of Volhynia, the purchase of the village Chlapotyna from knyaz Andrej Czetwertyński, and of the village Stawka from the Stawecki nobles ${ }^{6}$, and it is the last document related to transactions of knyaz Fedor. Afterwards, on $12^{\text {th }}$ of April 1545, he appeared on the king's demand at the military review at the Volodymyr castle. Two and a half years later, on $9^{\text {th }}$ of November 1547, he ordered his last will and testament to be written down. The original text in Ruthenian ${ }^{7}$ was published in Lviv in 1890 by Bronisław Gor$\mathrm{Czak}^{8}$, the custodian of the Archive of Sanguszko Princes in Sławuta.

The testator entrusted his soul and body to God, the Mother of God and All Saints, and instructed to be buried in the Kiev Pečersk Lavra, with his ancestors. He entrusted the care for his wife and children to the Lithuanian magnates, Jan Hlebowicz (the voivode of Vilnius and Chancellor of the Grand Duchy of Lithuania), Mikołaj Radziwiłł the Black (marshall of the Grand Duchy of Lithuania), Ivan Hornostaj (the court marshall), Konstanty Vasyl Ostrogski (the voivode of Troki), brothers and relatives (among them to his nephews, Aleksander and Jan Fedorovič Czartoryski). He instructed his wife and children to donate in his name (listed in the will) the monastic foundations, among those - in the key passage that is of interest to us - to the Xeropotamou monastery of St. Paul on Mt. Athos?. It was to receive annually the sum of 600 Lithuanian groschen $(\text { grosze })^{10}$.

Such donation, although common among the Lithuanian-Ruthenian princes and nobility ${ }^{11}$, who at that time were predominantly members of the Orthodox Church, is a phenomenon. The generous endowment of the Pečersk monastery, or of the Orthodox cathedrals in Vilnius and Brest are not surprising, nor are the donations to the monasteries and churches on the Sanguszko ancestral lands, nor even the large sum that the testator left for finishing the construction of the monastery of St. Nicholas in Mielce, which he founded (just as his relative, Michał

\footnotetext{
4 B. Gorczak, Katalog pergaminów znajdujących się w Archiwum X.X. Sanguszków w Sławucie, 61, Sławuta 1912, p. 32-33 (cetera: B. GorCZAK, Katalog pergaminów).

5 B. GorczaK, Katalog pergaminów..., 89, p. 46-47; 91, p. 47-48; 104, p. 53-54; 159 and 160, p. 77; 179 and 180 , p. 85-86; 202, p. 95-96.

6 B. GorczaK, Katalog pergaminów..., 202, p. 95-96.

7 A. JabŁonowski, Przedmowa, [in:] Rewizya zamków..., p. III.

8 L. cit.

9 B. Gorczak, Archiwum..., p. 564.

101 Lithuanian groschen (Lith. grašis, Rus. groš) = 1,25 of Polish groschen (Pol. grosz) (ca. 2,5 g); cf. J.A. SzwaGrzyK, Pieniadz na ziemiach polskich X-XX w., Wrocław 1973.

${ }_{11}$ On the subject of Old Polish wills cf. B. PopIOŁeK, Woli mojej ostatniej Testament ten... Testamenty staropolskie jako źródło do historii mentalności XVII i XVIII wieku, Kraków 2009, passim, esp. p. 13-30.
} 
Bohusz Bohowitynowicz, did $)^{12}$. What is astonishing is the attention devoted to the monastery of St. Paul ${ }^{13}$, located so far away from the ancestral Volhynia. It was, similarly to other monasteries on Mt. Athos, for two centuries under the patronage of Serbian rulers, and within their sphere of interest, which found its apogee in the capture of the peninsula by Stephen Dušan in 1345. This patronage was not eliminated by the peninsula's subsequent recapture by the Byzantine Empire. As it is known, donations to Mt. Athos, based on similar activities of the Byzantine emperors, became with time a typical example of the Serbian rulers' piety, both in the Nemanjic family as well as later, which is important in the context of the will discussed here, their heirs, in time only titular, the Branković family. Similarly, many of the Danubian princes were benefactors of monasteries, among them that of St. Paul of Xeropotamou, which did not change after the fall of Byzantium and under Turkish rule.

The key, as we think, to solving the mystery of the will donation, is the person of Hanna (Ganna - in the original will), the wife of knyaz Fedor Andreevič. She was most likely the daughter of the titular despot of Serbia during 1496-1502, John (Jovan) Branković ${ }^{14}$, who passed away on $10^{\text {th }}$ of December 1502. From this it would follow that Anna's birth should be dated to before 1502. The title of despot John Branković received from Vladislas II, the king of Hungary. He was the last Serbian ruler from the Branković family, and a continuator of the traditional patronage of the Serbian rulers over monasteries, including the one of St. Paul of Xeropotamou on the Holy Mount Athos. In 1505 he was created a saint, under the name of Despot John. Let us add, that the mother of Hanna/Anna, Jelena Jakšić ${ }^{15}$, called „Helena despotissa” came from a similarly noble family. Anna had four siblings - sisters: Milica, married to the Voivode of Wallachia, Neagoe Basarab; Maria, married to Ferdinand Frangepan; Helena, married to prince

${ }_{12}$ Cf. e.g. the testament of Ivan Hornostaj with quite similar list of monasteries and churches (including Vilnius, Kiev, Lutsk, Brest', but also Židičin, Zimne, Volodymyr Volynsky) - Н. Слгж, Сям’я Івана Гарнастая, падскарбія ВКЛ, БГЗ 38, 2012, р. 34-36.

${ }^{13}$ On the subject of this monastery see e.g.: S. Binon, Les origines légendaires et l'histoire de Xéropotamou et de Saint-Paul de l'Athos, Louvain 1942; M. SKowroneк, Przyczynek do historii biblioteki klasztoru Świętego Pawła na Górze Athos, [in:] Święta Góra Athos w kulturze Europy, Europa w kulturze Athosu, ed. M. KuCZyŃsKa, Gniezno 2009, p. 222-230.

${ }^{14}$ Such filiation was proposed by T. WASILEWSKI, Przyczynki źródłowe do stosunków Polski ze Stowiańszczyzna południowa w wiekach XIII-XVI, SŹ 8, 1963, p. 120-123. It was, one should add, questioned more recently. It is possible that Hanna was the daughter of Helena Jakšić from her second marriage, with Ivaniš Berislavić (I. Czamańska, Wiśniowieccy. Monografia rodu, Poznań 2007, p. 42; Z. ANUsIK, O książętach Wiśniowieckich i czasach, $w$ których żyli. Suplement do monografii rodu, PNH 8.2, 2009, p. 163-165) and was born after 1502. In the context of the matter discussed here it does not make much difference, since either way she was brought up in an environment in which the ties with Mt. Athos were strong.

15 T. WAsilewsKi, op. cit., p. 120-123. It is worth noting that she had ties to Mt. Athos as well. Cf. K. Mitrović, Povelja despotice Jelene Jakšić manastiru Hilandaru, CCA 7, 2008, p. 195-203. 
of Moldavia, Peter IV Rareş; and Magdalena (Maria Magdalena), from ca. 1538 the second wife of knyaz Iwan Wiśniowiecki (d. 1542) ${ }^{16}$. Anna's paternal grandparents were: Stefan Branković, called the Blind, the transitory despot of Serbia during 1458-1459 and also a benefactor of the monasteries on Mt. Athos, and Angelina Arianites. Hanna, we may presume, fully felt herself to be a continuator of the great traditions of her Balkan ancestors. After Fedor Andreevičs death she married once more, to the starosta of Krzemieniec (Kremenec), Mikołaj Zbaraski. She died in 1579. She had six children from her marriage with knyaz Sanguszko: Dymitr (Dmitri), Andrzej (Andrej), Roman, Jarosław, Fiodor (Fedor) and Magdalena (Maria Magdalena) ${ }^{17}$. The date of Fedor and Anna's wedding remains unknown. However, because their oldest son Dymitr was born ca. 1530, the marriage should also be dated to this period. It needs to be emphasized that in the Archiwum książat Sanguszków w Sławucie, over ten documents from the 1549-1570 period are listed, showing legal disputes surrounding the assets left by Fedor, in which Anna Despotissa is one of the parties, often admonished by the king, against her children from the first marriage ${ }^{18}$. Although the above documents show the knyaginya's activity, preserved and documented only under her name from the second marriage $^{19}$, with the exception of the will of Fedor Sanguszko, they do simultaneously present her character. Anna appears to have been a strong personality ${ }^{20}$, occasionally acting with disregard for the interests even of her own children. The death of her two sons, in tragic circumstances and at a relatively young age, certainly did not bring her any joy. Dymitr (1530-1554) in particular went down in history, due to the consequences of forcing Elżbieta (Halszka) of Ostrog to marriage (1553). This deed caused infamy and necessitated fleeing abroad. Dymitr's life ended soon afterwards, in Jaroměř, where he was killed by Marcin Zborowski ${ }^{21}$.

16 W. Dworzaczek, Genealogia, Warszawa 1959, vol. II, Tablice, tabl. 87, 88, 176. On the subject of Ivan Wiśniowiecki see I. CzAmańskA, op. cit., s. 37sq; Z. Anusık, op. cit., p. 156sq. Magdalena, similarly to Hanna, may have been a daughter of Jelena Jaksić from her second marriage. It may be useful to mention that Anna Glińska, Jelena Jaksić's sister, was grandmother of Ivan IV the Terrible.

17 M. Machynia, Sanguszko Fiodor, [in:] Polski Stownik Biograficzny (cetera: PSB), vol. XXXIV, p. 480-482, where older suppositions regarding Anna’s origins can be found; J. HaWryluk, Książęta Sanguszkowie na wołyńskich i podlaskich włościach, НБН, 2007, fasc. 5(93), p. 29.

18 Archiwum Ksiąząt Sanguszków w Stawucie, documents dated: 19 V 1549 (vol. VI, LVIII, p. 93-94); 5 XI 1552 (vol. VI, XC, p.130); 7 XI 1552 (vol. VI, XCI, p. 131); 7 XI 1552 (vol. VI, XCII p. 131-132); 12 XI 1552 (vol. VI, XCIII, p. 132-133); 6 III 1553 (vol. VI, XCVI. p. 136-137); 6 III 1553 (vol. VI, XCVII, p. 137-138); 10 III 1553 (vol. VI, XCVIII, p. 138-139); 9 V 1554 (vol. VI, CXVII, p. 218); 3 III 1557 (vol. VI, CXIX, p. 219); 23 I 1562 (vol. VI, CXXII, p. 222); 23 I 1562 (vol. VI, CXXIII p. 223); 1 XI 1570 (vol. VI, XLVIII, p. 68-69).

19 T. WASILEWSKI, op. cit., p. 120-123.

20 W. Łozıński, Prawem i lewem. Obyczaje na Czerwonej Rusi w pierwszej połowie XVII wieku, ed. J. TAZBIR, Warszawa 2005.

${ }^{21}$ On the subject of the marriage of Dymitr and Halszka and the tragic end of her life cf.: S. ZAGórSKA, Halszka z Ostroga. Między faktami a mitami, Warszawa 2006, p. 30sqq. See also M. Machynia, Sanguszko (Sanguszkowicz) Dymitr, [in:] PSB, vol. XXXIV, p. 471-473. 
The will donation of Fedor Sanguszko to the Holy Mount Athos, originating from Volhynia, which at that time was still a part of the Grand Duchy of Lithuania is, according to our knowledge, the first of its kind. We do not, however, know whether this part of the will was fulfilled, and whether the donation was used. Our attempts at obtaining such information did not bring results ${ }^{22}$.

Regarding the matter of using Fedor Andreevič Sanguszko's foundation, it would be tempting to postulate that the money from the donation was used to fund the frescoes in the chapel of St. George, in the monastery of St. Paul, in $1555^{23}$. It is, however, impossible to say whether they were created by Theophanis Strelitzas known as Theophanes of Crete, himself - the artist who gave the Cretan, spiritualised school of iconography its classical form - or his sons, who were taught icon writing by their father. This school, much like its predecessor, known as Macedonian school, is considered to be more realistic, it does not use podlinniki that may be found in Rus. Athos would have been the next stop for the painter who, prior to the arrival on the Holy Mountain with his two son from Heraklion, already adorned with frescoes the monastery of St. Nicholas Anapafsas in Meteora, among which he created the Transfiguration and the Denial of St. Peter. In 1535 he adorned Monastery of Lavra, and in 1545 with his son painted the interior of the Stavronikita monastery, where in 1546 he created the famous Icon of Christ the Pantokrator. Afterwards he did not leave the Holy Mountain until 1558 or early 1559; shortly prior to his death he returned to Crete, where he passed away ${ }^{24}$. In the present state of knowledge, to verify our assumptions seems, alas, beyond our reach.

Translated by Michał Zytka

\author{
Bogusław Andrzej Baczyński \\ Małgorzata Baczyńska \\ ul. Romanowicza $38 \mathrm{~B} / 2$ \\ 33-100 Tarnów, Polska \\ baczyn@op.pl
}

\footnotetext{
${ }^{22}$ Thanks to the kindness of Fadon Chatziantoniou we were able to contact father Nikodimos Agiopavlidis, who is responsible for the matters of historical heritage in the monastery of St. Paul of Xeropotamou (24 $4^{\text {th }}$ of April 2013). It turned out, however, that there is no knowledge of the donation at the monastery, and the documents confirming it have most likely not survived, despite the fact that the monastery's library contains 494 manuscripts and approximately 12500 books (I. TAVLAKIS, Monastery of Agios Pavlos, http://www.macedonian-heritage.gr/Athos/Monastery/Agios\%20Pavlos.html).

${ }^{23}$ I. TAVlakis, Monastery of Agios Pavlos: The monastery has 12 chapels, of which the most important one is that of St. George, with Cretan school frescoes from 1555. The justification for our proposal we intend to present elsewhere.

${ }^{24}$ On the subject of Theophanes and his works see, i.a.: M. CHATZIDAKIs, Recherches sur le peintre Theo-

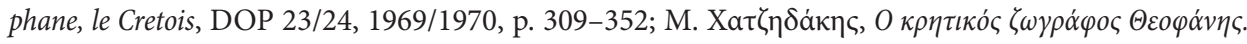

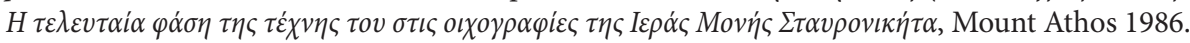




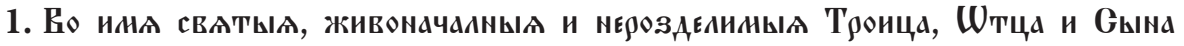

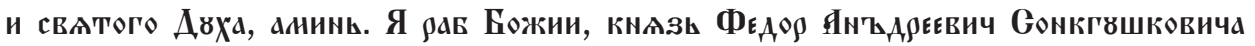

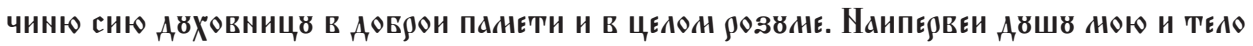

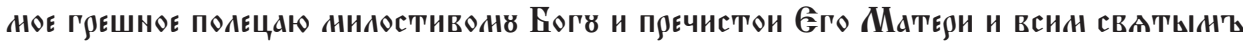

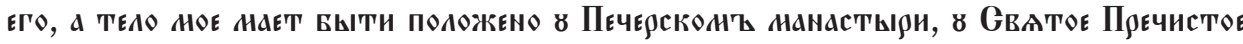

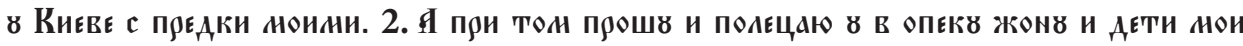

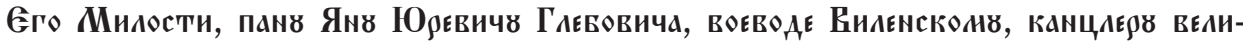
кого кназиства Митовского, а Gго Милости, панв Миколаю Радивиль, наршалкв

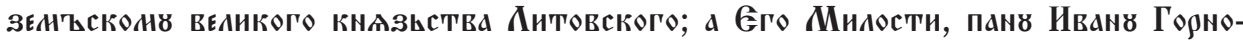

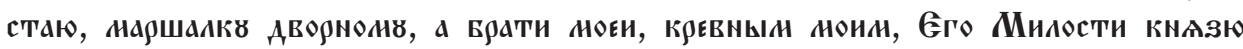

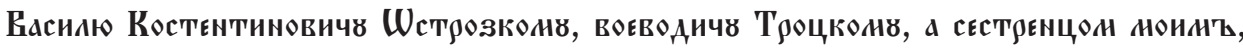

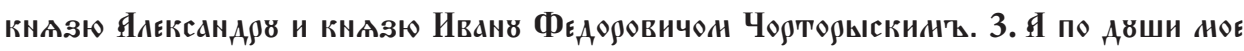

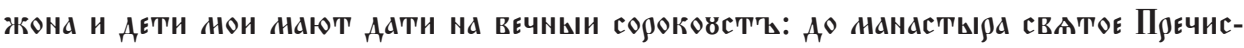

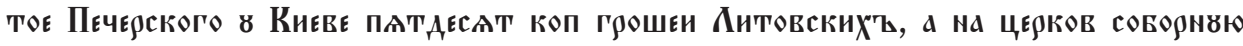

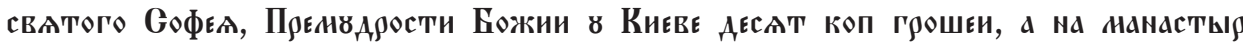

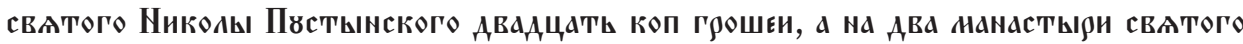

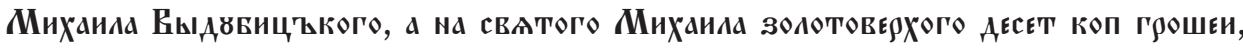

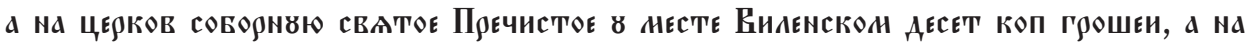

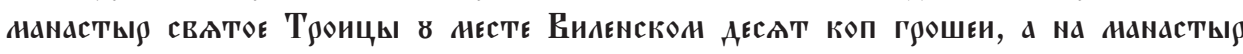

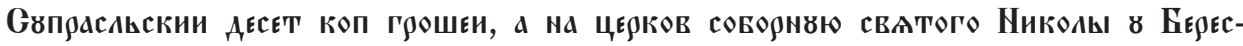

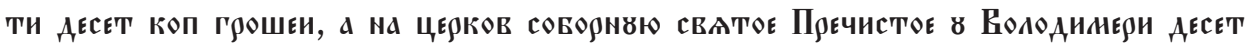

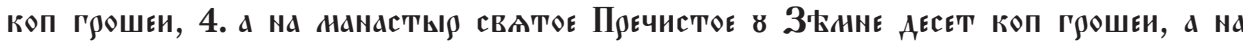

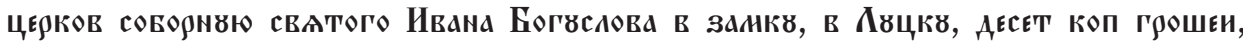

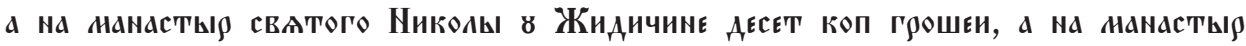

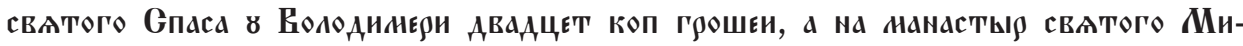

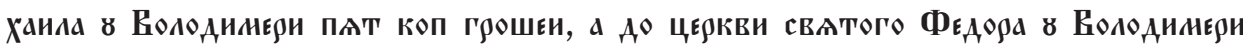

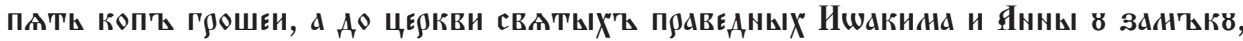

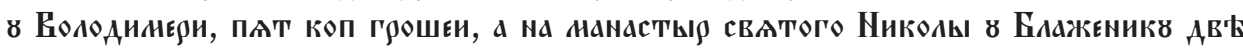

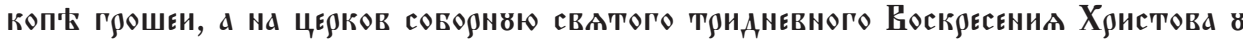

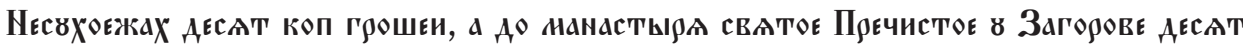

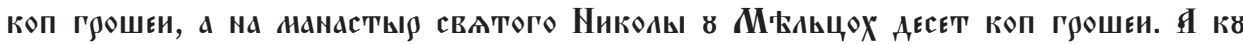

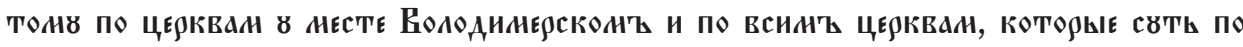

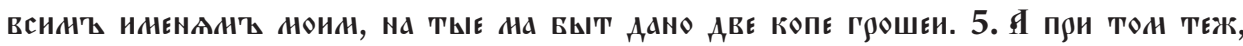

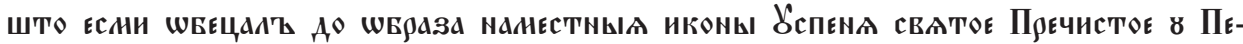

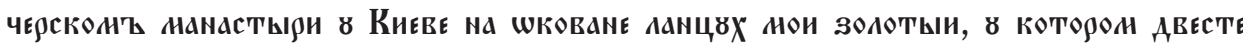

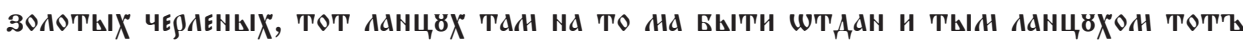

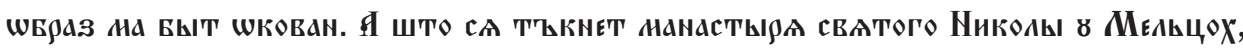
В НЕдОБУАОВАНИ ЦЕ९КВИ НУОУ И В НЕАОСТАТКУ СВАТТОСТЕИ, ШБЛАЗОВ, КНИГ И ОНЗ И ИНШИХ ПОТ९ЕБ ЦЕ९КОВНЫХ, ТОЕ ВСЕ ВОААВГ ПОТ९ЕБЫ ЖОНА И АЕТИ НОИ ЗО ВСИХ ИНЕМЕИ

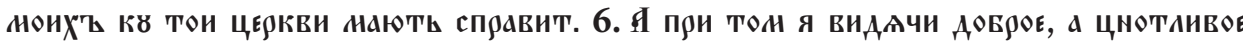

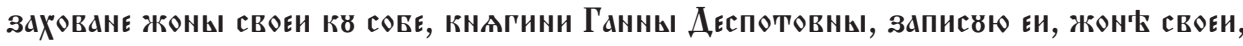




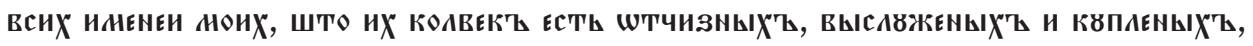

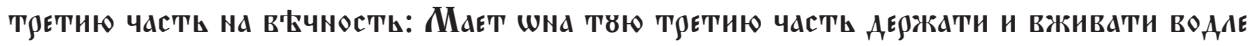

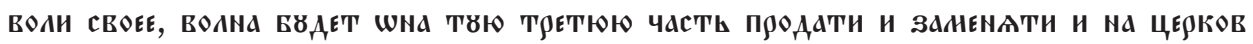
ШТПИСАТИ И ПО СВОЕН ЖИВОТТ КОНУ ХОЧЕТ, ТОДВ ИЗ ААСККИ СВОЕИ ВОАНА ЗАПИСАТИ,

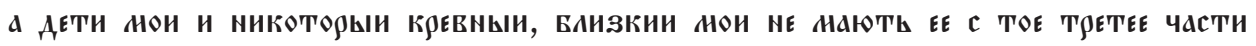

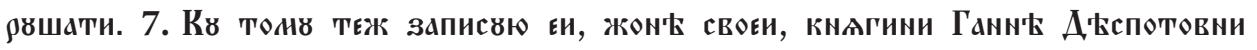

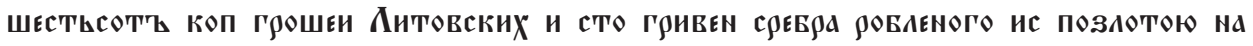

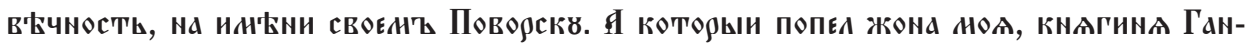

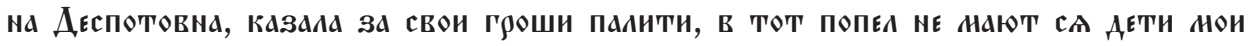

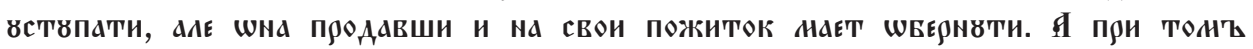

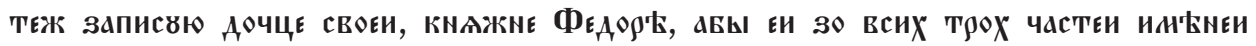

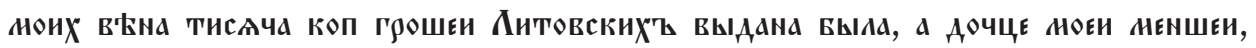

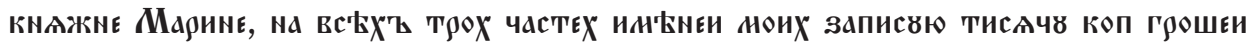

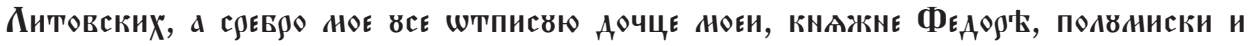

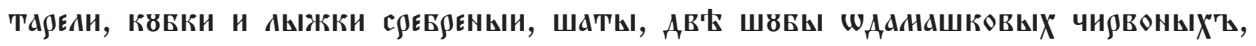

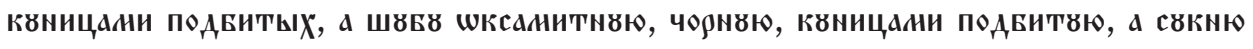

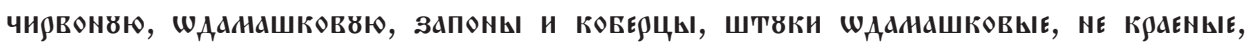

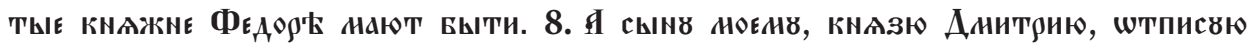

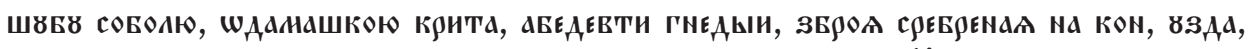

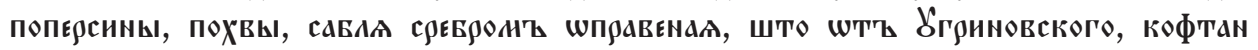

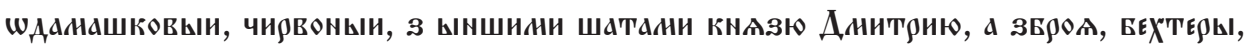

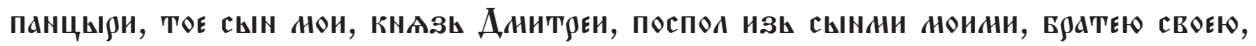

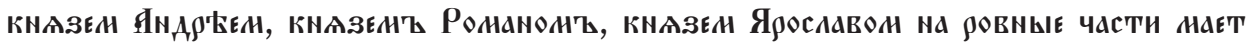

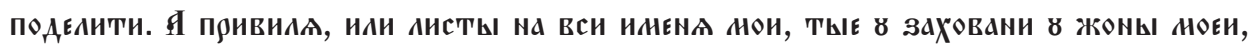

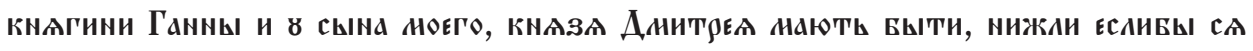

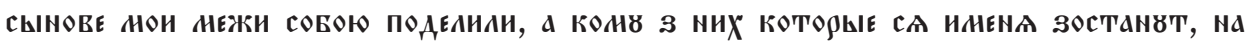

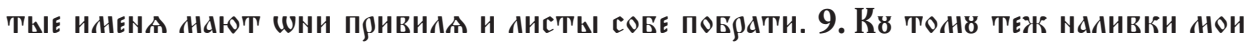

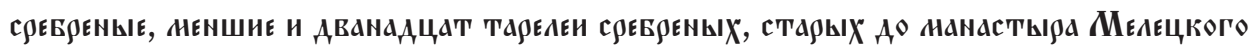

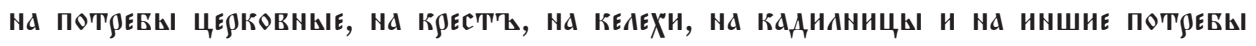

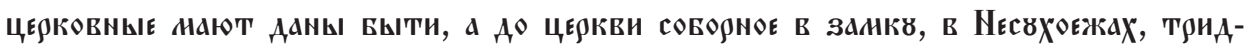
nевного Воскоесена Х ТЕЖ ЕСНИ АО Нанасты КОЖАЫИ ९ОК ПО АЕСЕТИ КОП Г९ОШЕИ, ТУЮ АЕСЕТИ КОП Г९ОШЕИ АБЫ ЖОНА И АЕТТИ НОИ

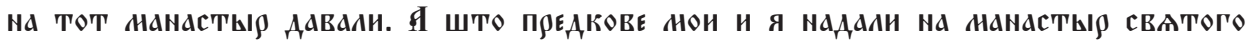

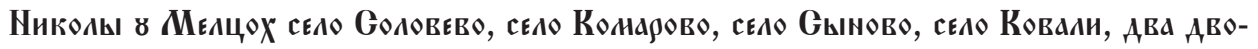

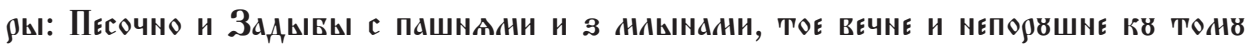

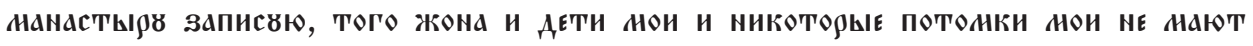

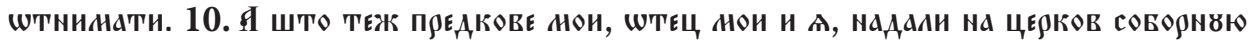

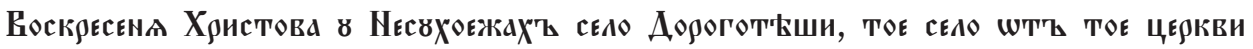

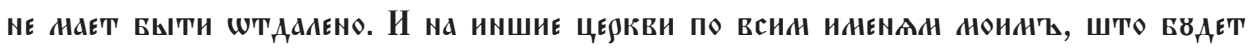

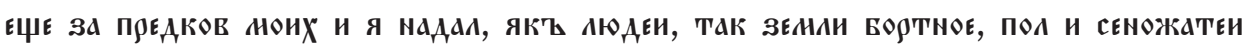




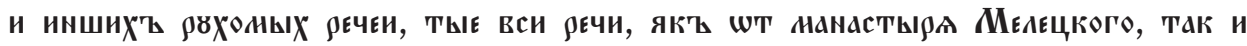

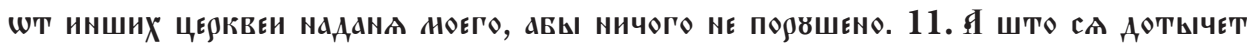

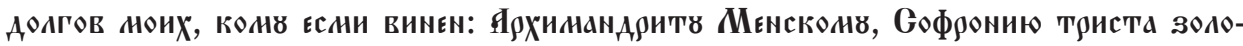

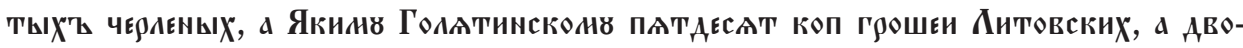

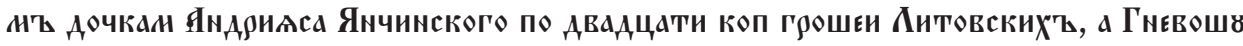

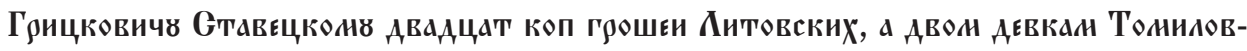

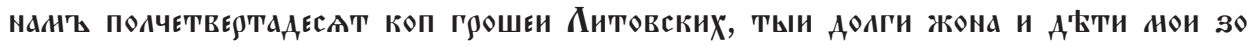
всИХ Т९ОХ ЧАСТЕИ НОИХ, АБЫ ПОПААТИАИ, АБЫ ТОГО НИЧОГО НА НОЕИ АЯШИ НЕ ЗААЕГАО. 12. Я ТО Я ЗАПИСУЮ ПОА КААТВОЮ СВАТЫХ ШТЕЦ ТЛИСТА И ШСН' НА АЕСАТ, ИЖЕ В'

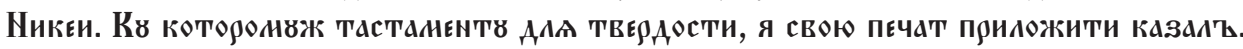
Я При тон Были: Gго Милость штец Генадин, владыка Володанерскин и Берестеискии, а сест ба нол, Пани Богушовал Боговитиновича, Подскарбинал зедһскал,

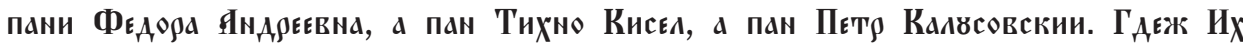

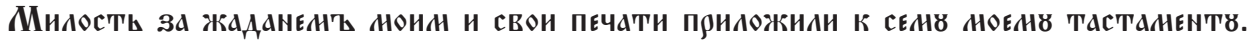

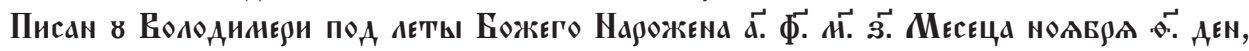
индиКтА S.

Reprinted from editio princeps: Archiwum książąt Sanguszków w Sławucie, vol. IV, ed. B. Gorczak, 1535-1547, Lwów 1890, p. 562-565, with internal divisions introduced in the present edition (abbreviations and sigla as resolved by B. Gorczak).

Original MS in: Archiwum Narodowe w Krakowie, Oddział I - Zamek Wawel, Archiwum Sanguszków, ASŁS ang. Per 242 (size 541 x 450 mm). 


\section{Testament of knyaz Fedor Andreevič Sanguszko(vič)}

1. In the name of the Holy and indivisible Trinity that is the beginning of life, Father, and Son and the Holy Spirit, amen. I, a servant of God, knyaz Fedor Andreevič Sonkguškovič hereby write this last will and testament, with good memory and whole ${ }^{1}$ mind. First and foremost I entrust my soul and my sinful body to the merciful God and His Most Pure Mother and to all of His saints, and thus my body is to be laid in the Pečersk monastery, at the Holy Most Pure ${ }^{2}$ in Kiev, next to my ancestors. 2. At the same time I ask and entrust the care of my wife and my children to His Grace, lord Jan Jurevič Glebovič̌ ${ }^{3}$, voivode of Vilnius, chancellor of the Grand Duchy of Lithuania, to His Grace lord Mikolaj Radiwil ${ }^{4}$, land marshall of the Grand Duchy of Lithuania, to His Grace Ivan Gornostaj ${ }^{5}$, marshall of the court, to my brothers, my relatives, His Grace knyaz Vasil Kostentinovič Ostrozki ${ }^{6}$,

\footnotetext{
I.e. 'clear, lucid, sane'.

2 Svjata(ja) Prečista(ja), i.e. the Mother of God. The Pečersk Lavra in Kiev was supported already by the knyaz's father, Andrej Aleksandrovič Sanguszko(vič), who was eventually laid to rest there.

3 Jan Jurevič Hlebowicz (Glebovič) - son of the Smolensk voivode, Jerzy Hlebowicz. He owed his career to queen Bona; he was the chief opponent of the Radziwiłł family in Lithuania. He was the voivode of Vitebsk since 1528, of Polotsk since 1532, of Vilnius since 1542, and Grand Chancellor of Lithuania since 1546; a first-rate diplomat, he was frequently an envoy to Moscow. He died in 1549.

4 Mikołaj Krzysztof Radziwiłł (Radivil) called Czarny (the Black) - creator of the family’s might, land marshall of Lithuania since 1544, Grand Marshall of Lithuania and Grand Chancellor of Lithuania since 1550, voivode of Vilnius since 1551. Received a ducal title from the emperor in 1547; supporter and propagator of Calvinism and Arianism (antitrinitarianism) in the Republic. An opponent of a closer union of Lithuania with the Crown, his influence on the king diminished near the end of his life. Died in 1565.

5 Ivan Ostafijevič Hornostaj (Gornostaj) - from a Kievian noble family, hospodarski (court) marshall since 1529 and simultaneously, from 1530, land treasurer; since 1538 an administrator of the Troki voivodeship, since 1549 of Vilnius voivodeship, he became a voivode of Nowogródek (Navharudak) in 1551. Trusted by both Sigismunds, an able administrator. Died in 1558.

6 Konstanty Vasyl (Konstantinovič) Ostrogski - starosta of Volodymyr (Volynsky) and marshall of Volhynia since 1550, voivode of Kiev since 1559, one of the mightier Lithuanian lords during the second half of $16^{\text {th }}$ century. Protector of the Orthodox Christianity in the Republic, founder (ca. 1580) of the Ostroh Academy and a printing press (where, among others, the so-called Ostroh Bible was published); an opponent of the Union of Brest. Loyal towards Sigismund II Augustus, maintained good relations with Jan Zamoyski, exerted considerable influence on Polish politics since the Union of Lublin. Died in 1608.

Fedor Sanguszko has always been related to the Ostrogscy knyazes, as his mother, Maria, came from that family; she was the daughter of Ivan, sister of Konstanty Ivanovič and an aunt of Konstanty Vasyl. Fedor's father administered the Ostrogski estate during 1500-1507. Fedor himself took part in fighting the Tartars, under the command of Konstanty Ivanovič Ostrogski in 1527, and in 1537 under the command of Ilia (Elias) Ostrogski, who was Konstanty Vasyl's half-brother. After Ilia's death, Fedor became one of the commissioners overseeing the division of his estate between his daughter Elizabeth (Halszka) and Konstanty Vasyl.
} 
voivodits $^{7}$ of Troki, to my nephews, knyaz Aleksander and knyaz Ivan Fedorovič Čortoryski ${ }^{8}$. 3. And for my soul, my wife and children are to donate for eternal sorokoust' '; for the Pečersk monastery of the Holy Most Pure in Kiev, 50 threescore Lithuanian groschen ${ }^{10}$, and for the cathedral church of Saint Sophia, of Divine Wisdom in Kiev $^{11}-10$ threescore Lithuanian groschen ${ }^{12}$, and for the Saint Nicholas Pustynnyi Monastery ${ }^{13}$ - 20 threescore Lithuanian groschen, and for the two monasteries, Saint Michael Vydubic'ki Monastery ${ }^{14}$ and Saint Michael's Golden-Domed Monastery $y^{15}-10$ threescore Lithuanian groschen, and for the cathedral church of the Holy Most Pure ${ }^{16}$ in the city of Vilnius - 10 threescore Lithuanian groschen, and for the monastery of Holy Trinity ${ }^{17}$ in the city of Vilnius - 10 threescore Lithu-

\footnotetext{
7 Voivodits (Pol. wojewodzic, Lat. palatinida) 'son of a voivode'; Konstanty Vasyl Ostrogski was a son of Konstanty Ivanovič, the Grand Hetman of Lithuania, castellan of Vilnius, voivode of Troki. While the title of voivodits did not officially guarantee that he would take over the voivodeship after his father, it was nonetheless a common practice, and the voivode families constituted the most important group of the Polish and Lithuanian-Ruthenian aristocracy.

8 Aleksander Fedorovič and Ivan Fedorovič Czartoryscy - the sons of Fedor (Fiodor) Michałovič Czartoryski and a daughter (name unknown) of Andrej Aleksandrovič Sanguszko(vič), the sister of Fedor. Andrej Sanguszko and Fedor Czartoryski were involved in lengthy litigations over incomes from the Lutsk starostwo $(1523,1525-1526,1530)$. Aleksander Fedorovič was an able commander, fighting the Tartars during Sigismund I's reign, since 1542 no longer in active duty. He was the starosta of Volodymyr since 1554, and from 1566 he was the first voivode of the newly created Volhynian voivodeship. He died in 1571. Ivan Fedorovič, married to Anna Zaslavska (Zasławska), died in $1566 / 1567$, he was the ancestor of both of the main lines of the Czartoryski family, i.e. Korets (korecka) and Klevan (klewańska) lines.
}

9 Sorokoust' - Pol. Czterdzieścina, Bel. Саракавiны, a prayer or a common reading of the Psalter for the soul of the deceased, held for forty days after death.

1050 threescore Lithuanian groschen - i.e. 3000 Lith. gr. [50 x 60; threescore (Pol./Ruth. sing. kopa, pl. kopy) being conventional amount in transactions]. Cf. an. 10 in our article above.

${ }^{11}$ Saint Sophia's (Holy Wisdom) Cathedral of Kiev - one of the oldest and the most important temples of the Kievan Rus, a burial place of the Kievan great princes. Dated to the $11^{\text {th }}$ century (1017 or 1037), rebuilt multiple times, during the mid $-16^{\text {th }}$ century in considerable disrepair.

${ }^{12}$ Here and below: 600 Lith. gr.

13 Saint Nicholas Pustynnyi Monastery - one of the oldest monasteries of Kiev, founded perhaps by knyaz Mstislav Vladimirovič in 1113, built on the slope of the hill near Dneper. From $17^{\text {th }}$ cent. known also as the Little Nicholas Monastery or Slupskyi ('of the Pillar').

14 Saint Michael Vydubits'ki (Видубицький) Monastery - monastery located on the shore of the river Dneper, founded by the Vsevolod Jaroslavič, the grand duke of Kiev, later associated with duke Vladimir Monomakh and his family; one of the centres of intellectual life in Kiev during mediaeval times.

15 Saint Michael's Golden-Domed (Золотоверхий) Monastery - the first temple in this place in Kiev, associated previously with the family of Duke Sviatopolk II Izjaslavič, was destroyed by Tartars in 1240; the worship was renewed in 1496, and the temple was considerably expanded and decorated throughout the $16^{\text {th }}$ century.

16 The Cathedral of Vilnius - built on the orders of the Grand Duke Olgierd (Algirdas) in 13461348, in the still non-Christian Lithuania. After its dome collapsed in 1506, the cathedral church in Vilnius was rebuild, with royal permission, by Konstanty Ivanovič Ostrogski, brother of Fedor Andreevič's mother.

${ }^{17}$ Monastery of Holy Trinity in Vilnius - the first wooden temple was constructed thanks to the initiative of the wife of the Grand Duke Olgierd (Algirdas), Julianna of Tver (the mother of Vladislas II 
anian groschen, and for the monastery in Supras ${ }^{18}-10$ threescore Lithuanian groschen, and for the cathedral church of Saint Nicholas in Berest ${ }^{19}-10$ threescore $^{-1}$ Lithuanian groschen, and for the cathedral church of the Holy Most Pure in Volodimer $^{20}-10$ threescore Lithuanian groschen, 4. and for the Monastery of the Holy Most Pure in Zemne ${ }^{21}$ - 10 threescore Lithuanian groschen, and for the cathedral church of Saint John the Theologian in the castle in Luck ${ }^{22}-10$ threescore Lithuanian groschen, and for the monastery of Saint Nicholas in Židičin ${ }^{23}-10$ threescore

Jagiełło) during the mid- $14^{\text {th }}$ century; subsequently, a monastery was created there. The right to build a brick wall in place of the wooden one was granted with a royal privilege of Sigismund I to Konstanty Ivanovič Ostrogski, father of Konstanty Vasyl and uncle of Fedor Sanguszko, after the battle of Orša in 1514.

${ }_{18}$ Suprasl (Pol. Supraśl) - city in Podlasie in Poland, in the vicinity of the Knyszyn Forest, since 1501 the location of the developed over time monastery of the Annunciation and Saint John the Theologian, founded by the Nowogródek (Navharudak) voivode Aleksander Chodkiewicz with the permission royal permission of Alexander I and Sigismund I, and of the patriarch of Constantinople Joachim I. Centre of book copying, and the place where the Codex Suprasliensis was discovered.

19 Brest (Berest'e, Pol. Brześć Litewski, Brześć nad Bugiem) - Belarusian city upon the river Bug, close to the present Polish border, of historical importance as the seat of a starostwo, and subsequently a voivodeship, and the place of many congresses and meetings of the Commonwealth's sejm. The castle and starostwo of Brest was bought from the widow of Aleksander Januszowicz by the father of Fedor, knyaz Andrej Aleksandrovič Sanguszko(vič) in 1508.

Church of Saint Nicholas - originally gothic, from $14^{\text {th }}$ century. The place of signing of the Union of Brest in 1596.

${ }^{20}$ Volodymyr Volynsky (Pol. Włodzimierz Wołyński, Ruth. Володимер Волынский), the capital of one of the dukes from the Rurik dynasty, and one of the political centres of Volhynia. The estates of Sanguszko family were in large part located near Volodymyr, and the family itself had strong ties with that city, which can be attested by the number of times it is mentioned in this will. Andrej Aleksandrovič Sanguszko was a starosta of Volodymyr since 1507/1508.

The cathedral church of the Holy Most Pure in Volodymyr (or rather of the Assumption), founded by prince Mstislav Izjaslavič in the middle of the $12^{\text {th }}$ cent., remained the most important church of the city, almost untouched during the Tartar attacks in the $13^{\text {th }}$ and $14^{\text {th }}$ cent. The burial place of the princes of Volhynia.

${ }^{21}$ Zimne/Zymne (Ukr. Зимне, Pol. also Zimno) - a village upon the river Luh (Pol. Ług), $5 \mathrm{~km}$ to the south of the Volodymyr Volynsky. The Assumption Monastery at the Holy Mountain in Zimne (Ukr. Зимненський Свято-Успенський Святогорський монастир) and the cathedral with the churches of the Holy Trinity, St. Julianna and St. Barlaam, is perhaps the oldest monastery complex in Volhynia. In 1495 a new, brick cathedral church was founded by Fiodor Michalovič Czartoryski. The place of burial of the Czartoryski, Czetwertyński, Kozieka and other families.

${ }^{22}$ Lutsk (Pol. Łuck) - one of the sejm cities of the Grand Duchy of Lithuania, the seat of the starosta of Lutsk; this function was performed by the Sanguszko and Czartoryski families during the $16^{\text {th }}$ century (i.a. since 1522 by Fiodor Michalovič Czartoryski, since 1542 by Andrzej Sanguszko(vič) Koszyrski).

The church of Saint John the Theologian - the Orthodox cathedral of Lutsk, built within the upper castle, was a family temple of the Jaroslavič branch of the Rurikids with the status of the cathedral since at least the late $13^{\text {th }}$ cent.

${ }^{23}$ Židičin (Pol. Żydyczyn, Ukr. Жидичин) - a village in Ukraine (Kivercivskyi Rajon) upon the Styr river, to the north of Lutsk, with a monastery built at the latest at the beginning of the $13^{\text {th }}$ century, destroyed by the Tartars in 1496, subsequently rebuilt and provided with considerable land dona- 
Lithuanian groschen, and for the monastery of the Holy Saviour in Volodimer ${ }^{24}$ - 20 threescore Lithuanian groschen, and for the monastery of Saint Michael in Volodimer $^{25}-5$ threescore Lithuanian groschen, and for the church of Saint Theodore in Volodimer ${ }^{26}-5$ threescore Lithuanian groschen, and for the church of the Holy Pious Joachim and Anna in the castle in Volodimer ${ }^{27}-5$ threescore Lithuanian groschen, and for the monastery of Saint Nicholas in Blaženik ${ }^{28}-2$ threescore Lithuanian groschen, and for the cathedral church of the Holy Resurrection of Christ in Nesuchoež $e^{29}-10$ threescore Lithuanian groschen, and for the monastery of the Holy Most Pure in Zagorov ${ }^{30}-10$ threescore Lithuanian groschen, and for the monastery of Saint Nicholas in Mielce ${ }^{31}-10$ threescore Lithuanian gro-

tions by Styr. The monastery of Saint Nicholas in Židičin was linked since 1507 (i.e. Sigismund I's donation) with the Ostrogski family (it was Konstanty Iwanovič, the father of Konstanty Vasyl and uncle (mother's brother) of Fedor Sanguszko who received it at that time, along with the rights to patronage).

${ }^{24}$ The Holy Saviour, i.e. Christ as Salvator, Spas. The village Janowiec was legally attached to the monastery. Cf. an. 20.

25 The monastery of Saint Michael in Volodymyr - the first mention of the temple comes from $13^{\text {th }}$ century; it still existed in 1621 , and subsequently declined. The privileges and rights associated with the monastery were equally divided between Andrej Aleksandrovič (Fedor's father) and Andrej Michaiłovič Sanguszko.

${ }^{26}$ The church of Saint Theodore in Volodymyr - one of the minor churches in Volodymyr Volynsky, in decline at the time, fell into ruin by the end of $17^{\text {th }}$ century.

27 The church of the Holy Pious Joachim and Anna in the castle of Volodymyr - the church mentioned in Ipatievskaja letopis' (1291), fell into ruin most likely by the end of $16^{\text {th }}$ century. It should not be mistaken with a later Catholic church of the same name.

${ }^{28}$ The village Błaženik (Błażeniki), located north of the Volodymyr Volynsky, half way to Turijsk (Pol. Turzysk), belonged to the Sołtan family since donation by king Alexander until mid- $16^{\text {th }}$ century, and to Mikołaj Łysakowski in the latter half of that century. It is unclear whether the monastery of Saint Nicholas in Blaženik is the same as the monastery in the nearby Turupin (Turobin, Turopyn). ${ }^{29}$ Nesuchoeže (Pol. Niesuchojeże, now Ukr. Воля) - eponymous hereditary estate for the Sanguszko family line, located among the Volodymyr estates upon river Turia (Kovel rajon of modern Ukraine), which belonged to the family, along with Grabow and Košyr, since the time of the family's progenitors, i.e. Fiodor Olgierdovič and his son, Sanguszko Fedkovič. In 1502, after it was divided betwen Andrej Aleksandrovič (Fedor's father) and Andrzej Michałovič Sanguszko, it belonged to Andrej Aleksandrovič, and subsequently constituted the main part of Fedor Andreevičss estate. The Orthodox church of the Holy Resurrection of Christ, located on the castle grounds, similarly to the family's manor house, did not survive. After the Second World War Nesuchoeže itself was divided into four separate villages. Further details concerning the church cf. below.

30 Zagorov (Pol. Ruth. Zahorów, Ukr. Загорiв) - two villages (Old Zagorov and New Zagorov), the seat of the Zahorowski family, with a monastery that existed there since the mediaeval period; the monastery was built in wood and requiring outlays. Less than three years after Fedor Sanguszko's death, his daughter Fedora married Piotr Zahorowski, and together they finalised the foundation, in 1567-1570 considerably expanding the monastery and donating lands to it. The monastery subsequently became a famed centre for icon writing and copying books.

${ }^{31}$ This religious complex is among the most closely connected with the Sanguszko family. Mielce (Ukr. Мильці), located near Nesuchoeže, were the subject of dispute of knyaz Andrej Aleksandrovič 
schen. And in addition, for the churches in the city of Volodimer and for all of the churches on all my lands, 2 threescore Lithuanian groschen [each] should be given. 5. Also in addition to this, [as] I had promised to [give] for the icon of the Dormition of the Mother of God in the Pečersk monastery of the Holy Most Pure in Kiev my golden chain for decoration, in which is 200 red zlotys, this chain is to be given for this purpose, and with this chain this icon is to be fitted. As for the monastery of Saint Nicholas in Mielce, unfinished church wall and insufficient [number of] holy things, icons, books, clothes and other items needed in the church, all of this my wife and my children, taking from all of my possessions, are to provide for this church. 6. And in addition to this I, seeing the good and virtuous conduct of my wife, knyaginya Ganna Despotovna, towards me, I leave her, my wife, a third part of all of my lands, however many of them there might be: inherited from my father, received for service and purchased, for eternity. She is to administer and use this third part according to her will, she is free to sell, trade or donate to the church this third part, and after the end of her life she may leave it to whomever she wills, and my children and some of my relatives, my close ones, are forbidden from ousting her from that third part. 7. In addition I also leave to her, my wife, knyaginya Ganna Despotovna, 600 threescore Lithuanian groschen and 100 grivna of gilded silver for perpetuity, in my estate in Povorsk ${ }^{32}$. And the ash, which my wife, knyaginya Ganna Despotovna ordered to be made at her own expense $^{33}$, to this ash my children should make no claim, but she, having sold it, is to use it for her own benefit. In addition I will that my daughter, knyažna Fedora ${ }^{34}$, should receive from all three parts of my estate a dowry of 1000 threescore Lithuanian groschen, and to my younger daughter, knyažna Marina ${ }^{35}$, from all three parts of my estate I leave 1000 threescore Lithuanian groschen, and all my silvers I leave to my daughter, knyažna Fedora: serving plates and plates, silver mugs and spoons, clothes, two damask šuby ${ }^{36}$ red, trimmed with marten fur, and velvet šuba,

(Nesuchoeže branch) with knyaz Vasyl Michałovič (Kovel' branch). The latter eventually conceded the monastery to Fedor Andreevič in 1533 according to the so-called Mielce settlement (ugoda mielecka), in return for other religious buildings and villages. The church of St. Nicholas was founded by Fedor Sanguszko on $23^{\text {rd }}$ of May 1542. Hanna Despotissa was buried there in 1579.

${ }^{32}$ Povorsk (Pol. also Powórsk, Poworsko) - settlement located half way between Kovel' and Manevyči, at the beginning of $16^{\text {th }}$ century Konstanty Iwanovič Ostrogski. It should not be confused with Porsk - parts of this settlement, located further to the south, belonged to Fedor Sanguszko thanks to a royal donation made in 1536.

${ }^{33}$ Burning of ash for sale to merchants (mainly Jewish) from different parts of the Commonwealth brought considerable income to the Sanguszko family.

${ }^{34}$ Fedora - in 1550 r. married Piotr Bohdanovič Zahorowski; she received in dowry from her mother Podłoźce and Porsk, which triggered a conflict between Hanna and Fedora on one side, and the latter's brother, Dymitr. She died in 1575. Buried in Mielce.

${ }_{35}$ Maryna (Maria) - she died young, buried in Mielce.

${ }^{36}$ Šuba (Pol. szuba) - a form of an outer garment, long, lined with fur, usually costly and made of expensive materials. 
black, trimmed with marten fur and red, damask dress, window curtains and carpets, bolts of damask cloth, not cut - these are to belong to knyažna Fedora. 8. And to my son, knyaz Dmitri ${ }^{37}$, I leave the sable šuba, covered in damask, the bay steed, silver armour for the horse, bridle, breastplates, sheathes, the silver fitted ${ }^{38}$ sabre from Ugrinovski ${ }^{39}$, the red, damask caftan along with other garments [I leave] to knyaz Dmitri, and the armours, bechters, coats of mail - my son, knyaz Dmitri, together with my sons, his brothers, knyaz Andrej ${ }^{40}$, knyaz Roman ${ }^{41}$ and knyaz Jaroslav $^{42}$, are to split into equal shares. And the privileges and all of the papers [relating to] all my lands are to be kept by my wife, knyaginya Ganna and my son, knyaz Dmitri, and should my sons share between themselves, then to whomever of them the estates would go, they are to take the privileges and papers [relevant for] these estates. 9. In addition to this my silver vessels, the smaller ones and 12 silver plates, the old ones, are to be donated to the monastery in Mielce for the needs of the church: for the cross, chalices, incense burners and other church instruments, and for the cathedral church at the castle, in Nesuchoeže, dedicated to the Resurrection of Christ - two silver serving plates are to be donated. Regarding what I donated to the monastery of Saint Paul, which is on the Holy Mountain, annually 10 threescore Lithuanian groschen, these 10 threescore Lithuanian groschen let my wife and my children donate for this monastery. And regarding what my ancestors and I donated to the monastery of Saint Nicholas in Mielce: Solovevo ${ }^{43}$ village, Ko-

37 Dymitr Sanguszko (Sanguszkovič) - the eldest son of Fedor and Hanna, brought up at the royal court, for bravery in fighting the Tartars made starosta of Žitomer (Żytomierz) in 1548, subsequently of Kaniów (Kaniv) and Čerkasy. After his father's death and the second marriage of Hanna (with Mikołaj knyaz Zbaraski), he remained with her in a bitter dispute, into which the royal court became involved. The main participant, along with Konstanty Vasyl Ostrogski, of the raid on Ostrog, aimed at kidnapping and marrying to him Elżbieta (Halszka, Elisabeth) of Ostrog, the daughter of Ilia Ostrogski, an heiress to the estate and remaining under king's protection (1553). Sentenced in absentia, in an atmosphere of an international scandal, to infamy and death, he fled to Bohemia where he was captured and killed (1554).

38 I.e. with a silver handgrip.

39 Stanisław Uhrynowski - a royal courtier and owner of his family estate Uhrynów, tenant of Kołodno.

${ }^{40}$ Andrej (Andrzej) Sanguszko - died young, buried in the church in Mielce.

${ }^{41}$ Roman Sanguszko - brought up at the royal court, he fought in expeditions against Muscovy, under the command of Mikołaj Radziwiłł (Radivil) Rudy (the Red) and Konstanty Vasyl Ostrogski, later a commander himself. Starosta of Žitomer (Żytomierz) since 1557, the first voivode of the newly created Bratslav voivodeship (1566). He contributed to making the decision to join the Bratslav voivodeship and considerable parts of the Grand Duchy of Lithuania to the Crown in connection to the Union of Lublin. Court Hetman of Lithuania since 1569. He died in 1571, buried in the church in Mielce.

${ }^{42}$ Jaroslav Sanguszko - participant of the Livonian war of 1562, Lithuanian delegate for the Sejm, murdered in 1564 in Jareviče near Lutsk.

${ }^{43}$ Solovevo or Solovi (Pol. Sołowiewo) - a village half way between Mielce and Nesuchoeže. In the 1570s it still belonged, like the surrounding estates, to Roman, the son of knyaz Fedor. 
marovo ${ }^{44}$ village, Synovo ${ }^{45}$ village, Kovale ${ }^{46}$ village, two manor houses: Pesočno ${ }^{47}$ and Zadyby ${ }^{48}$, along with the arable fields and mills, for eternity and permanently I leave to this monastery, and this may not be taken back by my wife nor my children nor any of my descendants. 10. And what my ancestors, my father and I donated to the cathedral church of the Resurrection of Christ in Nesuchoeže: Dorogotieši ${ }^{49}$ village, this village may not be taken back from this church. And what was donated to other churches on all of my lands, what happened in the times of my ancestors and what I donated, both men and lands with apiaries, and shores, and meadows with hay, and moveable other things, all these things, both [given] to the monastery in Mielce, as well as other churches that were endowed by me, may nothing be taken from them. 11. Regarding my debts, [here are] those that I owe to: to archimandrite of Mensk Sophronius ${ }^{50}-300$ red zlotys, and to Jakim Goljatynskij $^{51}-50$ threescore Lithuanian groschen, and to [the] two daughters of Andrijas Jančynski ${ }^{52} 20$ threescore Lithuanian groschen each, and to Gnevoš Griškovič Stavecki ${ }^{53}$ - 20 threescore Lithuanian groschen, and to the two Tomilo ${ }^{54}$ girls 35 threescore Lithuanian groschen to be equally split [between them]. These debts may my wife and children pay off from all three of my parts [of estate], so that none

\footnotetext{
${ }^{44}$ Komarovo - a village between Synovo and Nesuchoeže.

${ }^{45}$ Synovo or Synove - a village in the Nesuchoeže estates, north-west of Mielce, on the far shore of the lake bearing the same name. It belonged to Fedor's father, knyaz Andrej Aleksandrovič, since the division of the family estates in 1502 .

${ }^{46}$ Kovale - a village in the vicinity of Mielce.

47 Pesočno (Pol. Piaseczno) - a village to the south west of Povorsko.

48 Zadyby - a village purchased by Fedor Sanguszko from Lewek Zadybski and his nephews (Hrycko, Juchno, Siemaszko) in 1536-1538. So-called Puszcza Zadybska (Zadyby Forest) was an important, also from economical perspective, part of knyaz Fedor's estate.

${ }^{49}$ Dorohotieši or Dorotyšče - a village south of Nesuchoeže, by the road to Kovel'. In 1570s it belonged to Roman Sanguszko.

${ }^{50}$ Sophronius (Sofronij) - he was an archimandrite of the Ascension monastery in Minsk during 1540s, after his predecessor, Vassian Šyška, left for the Pechersk Lavra (1541/42), and before the position was taken by Joseph, archimandrite from at least 1552 . He vigorously defended the monastery from the attempts to retake the previously donated estates, which is attested also by other (aside from this one) documents from this period.

${ }^{51}$ Jakim Goljatynskij - if identical with Daniło Jackovič Holatyński (as B. Gorczak assumed), he would be the owner of Holatyn (Golatyn, or Zvinogrod); the Holatyński family is said to be deprived of their premises by knyaz Fedor Sanguszko himself, who as contemporary source has it, treated them as slaves and married their sisters with peasants (lustration of the Volhynian castles, 1545).

${ }^{52}$ Andrzej (Andrijas Ivanovič) Janczyński - owner of the village and estates Kruchiniče, which, together with his brothers Tychna and Jan partially mortgaged and partially sold to Fedor Sanguszko in 1535, which was in part confirmed in 1536 by king Sigismund I. Subsequently in the Lokači (Łokacze) estates of knyaz Roman Sanguszko.

${ }^{53}$ Gniewosz Griszkowicz (Hnevoš Hriškovič) Stawecki(-Šyškinnič) - together with his brother Ivan he sold to Fedor Sanguszko Stawek, the village on the river Turia belonging to his family, in 1538 (this was confirmed by Sigismund I in 1539 and 1541). It remained in the Nesuchoeže estates since.

54 Tomiło (Tomiłówne) sisters - unidentified.
} 
of this may hang on my soul. 12. And this I sign under the oath on the 318 holy fathers, who were at Nicaea ${ }^{55}$. To this will and testament, for permanence, I ordered my seal to be attached. This was witnessed by: His Grace father Gennadius ${ }^{56}$, the bishop of Volodimer and Bereste and my sister, Bogušova Bogovitinovič, the wife of district treasurer, lady Fedora Andreevna ${ }^{57}$, and sir Tichno Kisel ${ }^{58}$ and sir Piotr Kałusovskij ${ }^{59}$. Here also Their Graces on my request attached their seals to this testament of mine. Written in Volodimer, from the birth of Christ 1547, on the ninth day of the month of November, 6 indiction.

Translated by Michał Zytka and Zofia Brzozowska Annotated by Andrzej Kompa

\footnotetext{
55 Nicaea - sc. at the ecumenical council of 325 A.D.

${ }^{56}$ Gennadius (Gennadij, Henadej) - bishop of Volodymyr and Bereste (Brest') between 1536-1547.

57 Fedora Andreevna (Fedja, known as 'Pani Bohušova') - died in 1557, the wife of Bogusz Michal Bohowitynowicz (Bohovitynovič), who died in 1530 and was the land treasurer of Lithuania. $\mathrm{He}$ came from a Volhynian boyar family and was a leading diplomat, political writer and an able administrator during Sigismund I's times. His wife survived him by many years, and was respected among the Lithuanian-Ruthenian and Polish nobility. Already a widow at the time, she married off her daughters to members of Polish noble families.

58 Tichno (Tychno) Kisiel - Volodymyr judge, often witnessed the documents produced by the Nesuchoeže line of the Sanguszko family.

${ }^{59}$ Piotr Kałusowski - a Lithuanian courtier, often witnessed the documents produced by the Nesuchoeže line of the Sanguszko family.
} 